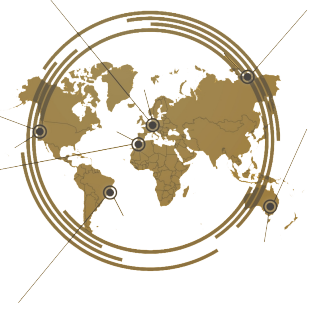

\title{
Brain-based learning and high order thinking skills effect on students' writing ability
}

\author{
Mukminatus Zuhriyah*, Ria Kamilah Agustina \\ English Education Department, University of Hasyim Asy'ari tebuireng Jombang, Indonesia
}

In this study, the researchers implemented brain-based learning (BBL) model and the use of the students' high order thinking skills (HOTS) in the teaching and learning of writing. The aim of this study was to know whether or not there was an interaction effect between teaching models and students' HOTS on the students' writing ability. This experimental research used a 2x2 factorial design. Two classes of the fourth semester of English Language Department became the population and the sample in this study. The students in both of the classes were divided into the students with high and low HOTS. Then, the experimental class was taught writing by using BBL and the control class used guided writing. Next, the data got from the writing test were calculated by using a two-way ANOVA. The result showed that $F_{o}$ interaction (10.160) was higher than $F_{t}(4.15)$ at the level of significance $\alpha=0.05$. It means that there was an interaction effect between teaching models and students' HOTS on the students' writing ability. The mean score of the students with high HOTS taught by using BBL (82.44) was the highest. This brings to the conclusion that BBL and HOTS had significant interaction effect on the students' writing ability.

Keywords: Writing Ability, Brain-based Learning, High Order Thining Skill

\section{INTRODUCTION}

As EFL learners, most of Indonesian students still fail to master English well (Marlina, 2013). These difficulties can happen because there are some differences between Indonesian language and English language. The first difference is that those two languages have different ways in arranging the sentences. Rahayu (2015) stated that the structure of Indonesian language is totally different from English. The second is that there is no difference of how to pronounce and how to spell the words in Indonesian language. In line with this, Donal (2016) explains that in general, the spelling and the pronunciation of the words of Indonesian language are the same. But the differences in the sounds and the spellings of the words do happen to English language. These differences often confuse the EFL learners very much.

Furthermore, the phenomenon of English teaching and learning in Indonesia tells that writing becomes the most complicated English skill for almost all the English department students. The students find many difficulties when doing English writing. They often do misspelling of some words that are actually very familiar in their speaking practice. Their grammatical struc tures on their sentences are often incorrect. Moreover, they get difficulty to collect the ideas for their writing. Because of those, they consider that writing is very difficult. Their lack of vocabulary, understanding of grammar, motivation and confidence cause them difficult in creating writing (Yulianti, 2018). 
However, it is very important for them to be able to communicate with others through written text because there will be some occasions in which they cannot tell or say what they want, feel and need orally or through face to face directly. Then, they need to learn writing indeed. They have to learn how to make the readers of their writing understand the messages on their writing well. They must transfer their willingness appropriately into the text.

Writing is a communication way through the written texts. Writing expresses the feelings, the thoughts, the ideas and the opinions of the writers. These writers' messages must be expressed correctly and appropriately in the texts. Indrilla and Ciptaningrum (2018) argue that writing is the people's way to communicate their thoughts or feelings by visible signs which are understandable for both themselves and for all other people. In order to avoid the miss-understanding of the readers, the writers must write the messages as clearly as possible. The clear and understandable writing can be reached by pouring the messages in the correct indicators of writing. There are some writing indicators that must be followed by the writers. The indicators meant consist of content, organization of the text, vocabulary, mechanics and grammatical structure. It is strengthened by Hughes as cited in Sianna and Syawal (2017) who states that there are five writing components of writing in analytic scale, such as content, organization, vocabulary, language use and mechanics.

Preliminary study which was held by the researchers told that the students' writing ability in the fourth semester of English department at a private university was low. It was known from the documents of the writing scores of the students in the previous semester. Most of the students (24 students from 36 students) still got the score under 70 . Additionally, the information got from the previous lecturer of writing also said the same fact. They still had low ability in writing.

The questionnaire results explained that there were internal factors and external factors that made their writing ability become low. The internal factors were that they got difficulties in reaching the indicators of good writing and did not have high motivation in class of writing. The teaching model of writing that did not lead the students to be more active in writing was the external factor. Considering those, the researchers decided to focus on their study by implementing brain-based learning (BBL) in the teaching of writing. Brain-based learning (BBL) is a teaching model that can make the students become active in learning and maximize the use of their brains' functions in the process of teaching and learning. According to Uzezi and Jonah (2017), brain-based learning makes use of the different aspects of brain function to learn, assimilate, think and remember. Moreover, the researchers also invited the students to actively involve their high order thinking skills (HOTS) in the teaching and learning process of writing. High order thinking skill is a level of thinking which is based on Bloom's revised cognitive domain which consists of analyzing, evaluating and creating Tarwiyah et al. (2018).

There were many previous studies which applied brain- based learning in the English as foreign language classroom. Oghyanous (2017) found that the effect of brain-based teaching approach toward self-efficacy of EFL students in Iran was significant. Brain-based learning was also proven to be effective in developing listening skills of the students and consolidating the recalling and the retention of the students' vocabulary as well as maximizing the motivation of the students in learning the skills of language (Salem, 2017). This was followed by Khalil et al. (2019) whose research result showed that some speaking skills of EFL students were developed because of the effect of the implementation of brain-based learning in the speaking class. Additionally, Khalil (2019) found that critical writing skills of EFL students could be significantly developed by implementing program based on brainbased learning and emotional intelligence.

Then some studies about the use of HOTS in English language classroom had also been conducted. Purnama and Nurdianingsih (2019) found that HOTS instruction became an effective strategy for teaching speaking viewed from the students' motivation. A study by Indriyana and Kuswandono (2019) showed that in developing students' HOTS in reading skills, the teachers used some strategies, such as giving the students the divergent questions, creating groups of discussions, showing the objectives of the learning to the students, giving the students the feedback of the materials having been studied, and motivating them to use their critical thinking. Next, Sianturi et al. (2020) explained their study result that the ability of the students in writing descriptive text could be developed by using HOTS questions. However, among those previous studies, no research studied brain-based learning (BBL) and high order thinking skills (HOTS) in the language classroom especially in the writing class. Therefore, this study was conducted with the purpose to know whether or not there was an interaction effect between teaching models and students' high order thinking skill on the students' writing ability.

\section{METHODS}

This was an experimental research which used the design of a $2 \times 2$ factorial design. This factorial design required the formation of four treatment groups. Those four groups in this study comprised of:

1. The students who had high HOTS and taught writing by using BBL

2. The students with low HOTS and taught writing by using BBL

3. The students whose HOTS were high and taught writing by using guided writing

4. The students who had low HOTS and taught writing by using guided writing

This research was conducted in the fourth semester of English language education department of UNHASY (University of Hasyim Asyari). Almost all of the students of this English 
department comprise the students of Islamic boarding schools which are located near to this campus. There were two classes of the that became the population in this study. Because this research used total sampling, those two classes automatically became the sample. Each class consisted of 18 students.

By using the lottery, the researchers decided which class to be an experimental class and which class to be the control class. The students of each class were classified into the students with high and low high order thinking skill (HOTS) based on the scores of HOTS test. Then class A as the experimental class was taught writing by using BBL. Guided writing was used to teach writing in the control class which was class B. After getting the treatment for three times, each class got the posttest of essay writing. The data on this study was collected from this kind of writing test. Then data which were in the form of the writing scores of class A and class B were calculated by using a twoway ANOVA test. This kind of test was done after knowing that the data obtained were in the normal distribution and homogeneous.

\section{RESULTS AND DISCUSSION}

Because the data distribution was already normal and its homogeneity was tested, then, a two-way ANOVA test was applied. The researchers found that result of this study completed the results of the previous studies about brain-based learning (BBL) in the language classroom conducted by the former researchers. Table 1 explains the different things from this study and the former studies, and Table 2 presents the summary of a two-way ANOVA test result.

Based on the result of the calculations of a two-way ANOVA test above, it can be known that $\mathrm{F}_{o}$ columns by rows (interaction) was 10.160 which was higher than $\mathrm{F}_{t}(4.15)$ at the level of significance $\alpha=0.05$. The sig. 0.000 was also lower than significance $\alpha=0.05$. Those mean that there was an interaction effect between teaching models which were Brain-based learning and guided writing and students' high order thinking skills (HOTS) on the students' writing ability. In other words, it can be said that the ability of the students in writing was influenced by the teaching models used by the lecturer in the class and the high order thinking skills that they had. This result could become a proof that the models of teaching had significant impact toward the students' success in gaining the goals of teaching and learning especially in writing class. That was why the teaching models chosen by the lecturer was expected to create comfortable atmosphere of teaching and learning so that the students could feel enjoy and relaxed in following the process of learning writing. This could raise their spirit to do the best writing. It automatically improved the students' ability in writing. Moreover, this ability was also interfered by the use of the students' high order thinking skills. This HOTS completed the effort of students in having the good writing results.

In addition, the other fact also tells that the students who had high HOTS and were taught by using BBL had the highest mean score of writing. From Table 3, the highest average score of writing which was got by the students with high HOTS in the class of experiment was mostly caused by the model of teaching used in that class. It was Brain-based learning which gave many differences in the ways of teaching and learning to write from guided writing. Brain-based learning (BBL) makes the students use their brain actively. Students were not challenged to memorize in BBL class, but they were demanded to think. Besides that, BBL stimulated the students to become curious, innovative and inventive because the information which was served was only the stimulus. These, of course, were followed by the use of the high order thinking skills that they owned.

\begin{tabular}{lllll}
\multicolumn{6}{l}{ TABLE 3 $\mid$ The Writing Mean Scores of Four Groups } \\
\hline Class & HOTS & Mean & SD & N \\
Brain- & Low & 61.22 & 4.410 & 9 \\
Based & High & 82.44 & 3.575 & 9 \\
Learning & Total & 71.83 & 11.592 & 18 \\
(BBL) & Low & 62.44 & 4.003 & 9 \\
Guided & High & 74.67 & 4.848 & 9 \\
Writing & Total & 68.56 & 7.625 & 18 \\
(GW) & & & & \\
\hline
\end{tabular}

The students in an experimental class which was taught writing by using BBL were actively using their brains to think about what the lecturer was demanding. Their lecturer did not explain more about the material but the students had to find more information in order that they could reach the goal of the writing teaching and learning process. They used their brains to understand what their lecturer meant and intended to do when giving the materials of writing. Before being in groups, they got the chance to drink first, then, think and create their own questions to explore information so that they could add and extend their opinions related to the topics of writing delivered by their lecturer. This made them feel relaxed without any forcing in expressing their opinions. Flor et al. (2013) state that relaxation can wide the attention scope and increase concentration on the task. So that the students' relaxed feelings in this case could help them to get information about what to be written in their texts more and more by having discussions in their groups. Every member of the group had the same opportunity to have ideas to be poured in the writing. The students automatically used their HOTS on this writing phase.

The information which was not in detail yet made the students observe and search everything that had relations to the topic of writing. When searching the ideas, they also got the freedom to use the creativity that they had as much as possible so that they could create an idea that seemed new. Their HOTS also took a part in this session to use many original ideas from their own ideas because they were forbidden to look for the writing from the internet. It made them become innovative. In line with this, Girotra et al. (2010) argue that the process of innovation involves generating ideas, selecting ideas and opportunity. By combining all of the ideas of all the members of the discussion groups, the students could innovate from the 
TABLE 1 | The Differences of This Study from the Previous Sstudies

\begin{tabular}{|c|c|c|c|c|c|}
\hline The Differences & $\begin{array}{l}\text { Oghyanous } \\
\text { (2017) }\end{array}$ & Salem (2017) & $\begin{array}{l}\text { Khalil et al. } \\
\text { (2019) }\end{array}$ & Khalil (2019) & This study \\
\hline 1. Research focus & $\begin{array}{l}\text { The effect of } \\
\text { BBL toward } \\
\text { young EFL } \\
\text { learners' } \\
\text { self-efficacy }\end{array}$ & $\begin{array}{l}\text { BBL to improve EFL } \\
\text { leaners' listening skills, } \\
\text { retention of vocabu- } \\
\text { lary and motivation }\end{array}$ & $\begin{array}{l}\text { The BBL effect } \\
\text { to develop } \\
\text { EFL learners' } \\
\text { speaking skills }\end{array}$ & $\begin{array}{l}\text { A program based on } \\
\text { brain-based learning } \\
\text { and emotional intel- } \\
\text { ligence to develop } \\
\text { EFL students' critical } \\
\text { writing skill }\end{array}$ & $\begin{array}{l}\text { The effect } \\
\text { of BBL } \\
\text { and HOTS } \\
\text { toward } \\
\text { students' } \\
\text { writing } \\
\text { ability }\end{array}$ \\
\hline 2. Research subjects & $\begin{array}{l}\text { Young EFL } \\
\text { learners in the } \\
\text { age of 13-16 } \\
\text { years old }\end{array}$ & $\begin{array}{l}\text { EFL students of } \\
\text { English for Specific } \\
\text { Purposes (ESP) }\end{array}$ & $\begin{array}{l}\text { EFL sec- } \\
\text { ondary school } \\
\text { students }\end{array}$ & $\begin{array}{l}\text { EFL students of sec- } \\
\text { ondary school }\end{array}$ & $\begin{array}{l}\text { EFL stu- } \\
\text { dents of } \\
\text { English } \\
\text { department }\end{array}$ \\
\hline 3. Research location & Iran & Egypt & Egypt & Egypt & Indonesia \\
\hline
\end{tabular}

TABLE 2 | Summary of ANOVA Test Result

\begin{tabular}{lllllll} 
Source of Variance & Type III Sum of Squares & $\mathbf{d f}$ & Mean Square & $\mathbf{F}_{\mathbf{o}}$ & $\mathbf{F}_{\mathbf{t}}$ & Sig. \\
Columns by rows (interaction) & 182.250 & 1 & 182.250 & 10.160 & 4.15 & .000 \\
Between groups & $2795.639^{a}$ & 3 & 931.880 & & & \\
Within groups & 574.000 & 32 & 17.937 & & & \\
Total & 3369.639 & 35 & & & & \\
\hline
\end{tabular}

ideas of their friend in their groups. They made the best content of writing based on their groups' opinions which had been collected. When they were presenting the writing, absolutely all the groups had the different writing even though the lecturer gave the same topic to them. Every group had their own unique thinking about the topic which was delivered by the lecturer.

The students in the experimental class were accustomed to finding and gathering the unique ideas for their writing. They were also used to using the correct grammar and the appropriate diction. When discussion, they did corrections for the writing they made based on the suggestions and the explanations of their friends in the groups. Their knowledge of grammatical structure unconsciously increased because of it. The skill of selecting the most suitable vocabulary in expressing their ideas also got improvement because of the activity that they always did when discussing their writing. The skills of analyzing, evaluating and creating that the students whose HOTS was high worked well in this discussion. They could distinguish the right and wrong grammatical structure. They were able to differentiate the correct vocabulary. To sum up, it can be said that the peer corrections in this discussion could help the students to develop their writing. It is supported by Behin and Hamidi (2011) who explain that peer correction is beneficial in increasing the writing skill of the students.

They actively used their brain and HOTS in composing the best essay. They could define what the lecturer asked to do well. They were able to classify and identify the structures of the essay writing from the example which was given by their lecturer well. In the groups of discussion, this kind of knowledge was always discussed, and they also talked about the organization of this essay in the presentation time when they had to present the writing that had been made in their groups. In addition, the ways of the lecturer on asking them to create part by part of the organization of the essay writing in every discussion meeting help them to recognize every part of this essay organization more easily. They spoke more about every single part of this organization and also did more in creating the writing as well as thought more by activating their brains in getting the good content. Thus, all the conditions that happened to the students in the experimental class who learnt essay writing by using brain-based BBL model were the factors that made their writing ability become higher than that of the control class.

Meanwhile, the students in the control class who were taught writing of the essay by using guided writing acted differently from the experimental students. They looked to always wait the guidance from their lecturer. Most of them tended to be passive in the class of writing. They also seemed not to have high motivation to do the writing assignment. They also did not have high confidence of their ability because they always felt afraid of making many mistakes on their writing. All of these conditions of the students in this control class made their ability in essay writing get lower than those of experimental class. Besides, they seldom used their HOTS.

In the guided writing class, the lecturer gave the examples of every part of her explanations about essay writing. It was always followed by some instructions to be done by the students in doing the writing assignment in every meeting. The instructions were meant to make the students create the writ- 
ing more easily. The lecturer guided them with some leading questions when they were in the process of gathering ideas. Although they were already divided into groups, the lecturer still guided them. Anggrainy et al. (2016) state that in guided writing, the students collaborate with the teachers and other students before they write individually. Actually, the lecturer's purpose in giving the students' instructions in this guided writing was to make the students easy to get the ideas for their writing. But, the facts talked the different things. These instructions made them reluctant to use their brains more in getting and finding some new ideas which were related to the topics of writing which was asked by their lecturer. They seemed rare to use their HOTS as maximally as possible because they knew that their lecturer must have been going to help them in creating ideas. That was why the writing which they had presented often contained the same ideas from all of the groups.

When they had discussion time in the groups, only one student who dominated the discussion in every group. The other members of the groups only kept silent and listened to what their friends in the groups who were admitted the most capable talked about. They often agreed with everything that the leader of their group decided. They did not want to add the ideas by their own ideas. Their writing result when being presented was often still in disorder. It really showed that only one student who had done the writing. It was because meeting by meeting the mistakes that were often found in their writing were always various. The students who often asked and answered the questions in the discussion among groups were also the same students. The other students just followed the flow of the discussions without having any comments and suggestions as well as questions for the writing of other groups which had been presented. The students often had contributions in the discussions if the lecturer directly called their names and asked them to say something that could be in the form of comment, suggestion or question to the owner of the writing. Only in this time the students in this class seemed to use their HOTS in order to be ready if their names were called. Because of the demand of their lecturer, the students wanted to give their opinions or ideas in the discussion forum.

When the lecturer asked them whether they had already understood the materials of writing that was being learned or not, they also always told that they already understood. Moreover, the students whom the lecturer did not point to give ideas did not say anything even though they had already prepared their ideas. This situation made them have poor writing scores. To sump up, it could be said that most of the students were less in practicing all the stages of the writing process so that their writing ability became poor. Tuan (2010) emphasizes that the better writing ability can be got by practicing writing more.

The students in the guided writing class often appeared not spiritful to join the class. It caused them not to motivate to create the writing text as what their lecturer wanted. They were not motivated to finish their writing assignment as soon as possible. When the time for creating the text was already over, one or two groups only who could finish writing. Many of them always asked the extended time to do the writing. Some of them also asked whether it was permitted or not if they submitted their group writing in the following day. In the next day that they had promised, they did not collect or even send their writing if the lecturer pretended to forget or did not ask to submit their writing. This made them not know what was wrong and what was already correct and appropriate in their writing. In short, this low motivation led them to have low writing ability. Aryanika (2016) supports this by explaining that the students will face difficulties in writing without having strong writing motivation.

The students often showed that they were not confident about what they knew related to the essay writing. It could be known when they were pointed to give comments to their friends' writing. They were in doubt to tell their ideas about that writing. They were afraid of making mistakes in their comments that they would give to their friends. They did not have such kind of thinking that they could learn more by having some mistakes. They did not want to use their HOTS. What they had was only they would feel ashamed if their ideas in the comments or suggestions were not correct. They did not realize that they actually were learning to think critically when they tried to give their opinions based on the writing that had been written by their friends. Feeling afraid of the mistakes led them not to have confidence about writing. Mardiansyah (2018) argues that there are significant correlation and influence between students' self-confidence and their writing performance. It means that when the students have low selfconfidence, their performance of writing will become poor.

What the students in the control class had done made their knowledge of writing not increase well. Their knowledge about the structures of the essay writing was not as good as the knowledge of the students in the BBL class. The quality of the content of the writing that they created was also standard and not as inventive as the writing content that had been composed by the students of experimental class. Their mastery of the grammatical structure was also lower. The ability in using the appropriate vocabulary for expressing the ideas that they had was not good. They often used the words that they know the words well. Their mastery on writing indicators was not so good that it brought them to have writing ability in essay writing that was lower than the students of BBL class. Alrabah and hua Wu (2017) argue that writing ability covers the ability of writing both beyond sentence such as ideas, organization of the text and vocabulary and within sentence such as grammar.

\section{CONCLUSION}

Teaching models especially BBL and the use of HOTS had a significant interaction effect in the teaching and learning of writing. Since the implementation of brain-based learning (BBL) combined with high order thinking skill in teaching and learning process of writing is still rare, this study gives the new insight for all English teachers to use BBL and HOTS in the 
class of writing. The result of this research becomes the proof that BBL and students' HOTS had significant influence toward students' writing ability. BBL and HOTS can also be implemented in English language classroom such as teaching speaking, listening, and reading. It is also highly recommended being applied in many other courses in the teaching and learning process. Many specific areas of writing, for instance what writing indicator gets most effect of the use of BBL and HOTS in the teaching and learning to write, had not been explored yet in

\section{REFERENCES}

Alrabah, S. and hua Wu, S. (2017). Promoting Writing Competence and Positive Attitudes among College Students in a CLIL English Course. International Journal of English Linguistics 7, 58-58. doi: 10.5539/ijel.v7n1p58.

Anggrainy, S., Diem, C. D., Vianty, M., and Sugandi, B. (2016). The Effect of Graphic Organizers, Guided Writing Strategies, and Reading Levels on the Writing Achievement of the Fourth Semester Students of PGMI Program at IAIN Raden Intan Lampung. In Proceedings of the 2nd SULE - IC 2016. 1029-1052.

Aryanika, S. (2016). The CorrelationBetween the Students' Writing Motivation and the Writing Ability. English Education: Jurnal Tadris Bahasa Inggris 9, 215-232.

Behin, B. and Hamidi, S. (2011). Peer Correction: The Key to Improve the Iranian English as a Foreign Language Learners' Productive Writing Skill. Procedia Social and Behavioral Sciences 30, 1057-1060. doi: 10.1016/j.sbspro.2011.10.206.

Donal, A. (2016). Indonesian Students' Difficulties in Pronouncing English Diphtongs. Journal of English Education 2, 55-62.

Flor, R. K., Monir, K. C., Bita, A., and Shahnaz, N. (2013). Effect of Relaxation Training on Working Memory Capacity and Academic Achievement in Adolescents. Procedia-Social and Behavioral Sciences 82, 608-613. doi: 10.1016/j.sbspro.2013. 06.318.

Girotra, K., Terwiesch, C., and Ulrich, K. T. (2010). Idea Generation and the Quality of the Best Idea. Management Science 56, 591-605. doi: 10.1287/mnsc. 1090. 1144.

Indrilla, N. and Ciptaningrum, D. S. (2018). An Approach in Teaching Writing Skills: Does It offer A New Insight in Enhancing Students' Writing Ability. LLT Journal: A Journal on Language and Language Teaching 21, 124-133.

Indriyana, B. S. and Kuswandono, P. (2019). Developing Students Higher Order Thinking Skills (HOTS) in Reading: English Teachers Strategies in Selected Junior High Schools. JET (Journal of English Teaching) 5, 204-204. doi: 10.33541/jet.v5i3.1313.

Khalil, A. H. (2019). A Program Based on Brain-Based Learning and Emotional Intelligence for Developing EFL Secondary School Students' Critical Writing Skills. Journal of Faculty of Education 119, 51-74.

Khalil, A. H., El-Nagar, B. E. E., and Awad, M. A. E. (2019). The Effect of BrainBased Learning on Developing Some Speaking Skills of Egyptian EFL Secondary School Students. International Journal of Environmental \& Science Education 14, 103-116.

Mardiansyah, R. (2018). A Correlation between Self-Confidence and Essay Writing Achievement. A Correlation between Self-Confidence and Essay Writing Achievement. Edukasi: Jurnal Pendidikan Dan Pengajaran 5, 154-166.

Marlina, L. (2013). Learning English as Foreign Language in Indonesia through English Children's Literature. The International Journal of Literacies 19, 41-51. doi: 10.18848/2327-0136/cgp/v19i04/48801. this research so that the other researchers can do the research in the same area as this research deeply.

\section{ACKNOWLEDGMENT}

Kemenristek-BRIN funded this paper with contract between DRPM and LLDIKTI VII no. 083/SP2H/LT/DRPM/2020 and contract between LLDIKTI VII and University of Hasyim Asy'ari no. 045/SP2H/LT-MONO/LL7/2020.

Oghyanous, P. A. (2017). The Effect of Brain-Based Teaching on Young EFL Learners' Self-Efficacy. English Language Teaching 10, 158-158. doi: 10.5539/elt. v10n5p158.

Purnama, Y. I. and Nurdianingsih, F. (2019). The Impact of Higher Order Thinking Skills (HOTS) Instructions in Teaching EFL Speaking Skill from the Perspective of Students' Motivation. Lingua Cultura 13, 313-313. doi: 10.21512/lc.v13i4. 6105.

Rahayu, A. U. (2015). Differences on Language Structure between English and Indonesian. International Journal of Languages, Literature and Linguistics 1, 257260.

Salem, A. A. M. S. (2017). https://doi.org/10.5539/elt.v10n12p182.

Sianna, S. and Syawal, S. (2017). THE IMPLEMENTATION OF POEW IN TEACHING WRITING. International Journal of Language Education 1, 51-61. doi: 10.26858/ijole.v1i1.2871.

Sianturi, L. P. D., Silalahi, D. E., and Purba, C. N. (2020). Improving Students' Writing Ability based on Higher Order Thinking Skills (HOTS) Questions at 8th Grade in SMP Swasta Kartika 1-4 Pematangsiantar. JETAFL (Journal of English Teaching as a Foreign Language) 6, 1-17.

Tarwiyah, S., Warsono, W., Bharati, D. A. L., and Sutopo, D. (2018). Professional Learning through Coaching: toward the Enhancement of the Teachers' Pedagogical Competence. doi: 10.24093/awej/vol9no4.30. https:/dx.doi.org/10.24093/ awej/vol9no4.30.

Tuan, L. T. (2010). Enhancing EFL Learners' Writing Skill via. Journal Writing. English Language Teaching 3, 81-88.

Uzezi, J. and Jonah, K. (2017). Effectiveness of Brain-based Learning Strategy on Students' Academic Achievement, Attitude, Motivation and Knowledge Retention in Electrochemistry. doi: 10.9734/jesbs/2017/34266. https://dx.doi.org/10. 9734/jesbs/2017/34266

Yulianti, D. B. (2018). Learning strategies applied by the students in writing English text. Journal on English as a Foreign Language 8, 19-38.

Conflict of Interest Statement: The authors declare that the research was conducted in the absence of any commercial or financial relationships that could be construed as a potential conflict of interest.

Copyright (c) 2020 Zuhriyah and Agustina. This is an open-access article distributed under the terms of the Creative Commons Attribution License (CC BY). The use, distribution or reproduction in other forums is permitted, provided the original author(s) and the copyright owner(s) are credited and that the original publication in this journal is cited, in accordance with accepted academic practice. No use, distribution or reproduction is permitted which does not comply with these terms. 